Relations industrielles

Industrial Relations

\title{
Handling Shop Grievances
}

\section{Benjamin M. Selekman}

Volume 1, numéro 4, décembre 1945

URI : https://id.erudit.org/iderudit/1023921ar

DOI : https://doi.org/10.7202/1023921ar

Aller au sommaire du numéro

\section{Éditeur(s)}

Département des relations industrielles de l’Université Laval

ISSN

0034-379X (imprimé)

1703-8138 (numérique)

Découvrir la revue

Citer cet article

Selekman, B. M. (1945). Handling Shop Grievances. Relations industrielles / Industrial Relations, 1(4), 6-6. https://doi.org/10.7202/1023921ar

Tous droits réservés @ Département des relations industrielles de l’Université Laval, 1945
Ce document est protégé par la loi sur le droit d'auteur. L’utilisation des services d'Érudit (y compris la reproduction) est assujettie à sa politique d'utilisation que vous pouvez consulter en ligne.

https://apropos.erudit.org/fr/usagers/politique-dutilisation/ 


\section{HANDLING SHOP GRIEVANCES}

The heart oi the union agreement, it has often been said, lies in its grievance procedures. Certainly management and workers alike stand to gain from the operation of a communications system which brings difficulties at the bench to the attention of responsible authorities. Yet experience testifies abundantly that the best formal machinery of adjustment does not necessarily guarantee shop order. To realize the full potentialities of grievance machinery, we must concejve of adjustment procedures not only as the heart of the union agreement but as the very heart of shop relationships.

The distinction is crucial. For grievances are inextricably interwoven not only with objective shop conditions but with the whole texture of subjective shop relationships. The effectiveness of grievance machinery must be evaluated, therefore, not by reference to oontractual clauses alone but in terms of all that preceded their introduction and of all that conditions their continuing application.

Each complaint should be regarded as a symptom revealing the state of health characterizing relationships. And each complaint should be handled through the clinical approach to grievances and the grievance machinery - an approach that views complaints through the functioning processes of shop behavior by which men work together. In contrast, the present approach is legalistic.

Dissatisfactions among the men at work are fixed within relatively static categories of causation, chiefly by reference to written clauses of a contract current for a stated period of time. They are a reduced - a revealing word - to writing; they are delimited by labels that record them as disputes over vacations, or wage rates, or overtime, or work conditions, or whatever the specific claim may be. If the protest does not fall clearly within the purview of some defined, accepted job right or regulation, it is thrown out of court. If, on the other hand, it does relate to current shop law, it will be debated according to approved legalistic procedures under the established machinery of joint conference and appeal. And time and again everything may be neat and orderly in the adjustment of a grievance - save the behavior of the aggrieved.

Workers with grievances are, of course, affected by the arbitrary standards by which complaints are accepted as \& valid or rejected as * imaginary $\|$. Just as management and unions forge the clauses of the agreement into a tool for sifting out legitimate from illegitimate grievances, the workers adopt these same clauses as sanctioned forms of expression or all manner of dissatisiactione. If only wage complaints, protests against transfers, shift assignments and change in workloads, or other " just " causes are accepted as legitimate, employees often will unconsciously disguise quite varied fears and resentments in the sheep's clothing of the so-called valid complaint. When strong emotions are denied an outlet for expression in their own terms, they find ways of utilizing some other outlet. That is why it is so important always to remain aware of the powerful negative emotions that are inescapable components of grievances the sense of injury, of injustice, that mobilizes and then is fed by hostilities, fears and resentments. No complaint, to put it bluntly, will ever be completely or effectively shut off or dismissed. It may be driven underground, in the temporarily silenced individual or the deceptively acquiescent shop, only to reappear sooner or later, recast in sanctioned demands if possible or, if not, in shop unrest, walkouts, slowdowns, turnover, absenteeism, lack of discipline, clique hostility, and so on.

Use of the clinical approach to the grievance does not affect the basic aim of grievance procedure, which always remains, of course, the promotion of efficient production. It will not even transform in any fundamental way the steps by which treatment is initiated.
Instead, it will modify and expand prevailing procedures until orderly handling of complaints utilizes not only the law of the agreement but every instrument of control that psychological and social insights make available.

Thus the first task before the foreman or steward to whom the complaint is presented is to get the facts. This means more than merely hearing the story of the complaint. It may involve consultation with a whole department, or even the investigation of conditions in another mill, through the machinery of the national union. In addition, management's side of the story is needed to complete the picture. After the foreman has marshaled all the available facts for testing the objective merits of a claim, he should next determine exactly what kind of grievance he is facing. Before he takes action - and action should be taken on every grievance he receives - he should ask himself the following questions : Has the complainant been involved in grievarces before? If so, what settlements were made? If the complaint involves a group, is that group composed of employees who often seem to act together. Is there some formal, organizational reason why they all should press the claim? Does any one of them seem particularly active in it? Does the aggrieved employee show feelings that seem excessive or out of line with the situation? What kind of feeling? Does some factor in connection with his job seem to be rousing fear or resentment in him? Is the complainant facing any trouble outside the shop?

The investigation of a complaint, then, should not be considered complete until these two highly important bodies of facts have been compiled : 1) the evidence by which the foreman or steward can deride whether the grievance submitted to him presents a valid case, within the terms of the agreement, and 8) such data as may indicate the degree to which factors of personality, feelings, sentiments, group alignments, and so on, underlie its genesis or threaten to complicate its handling.

At first encounter, the clinical approach may appear to project heavy burdens upon foremen and stewards, and also upon higher company and union officials. Can we ask busy people to engage in exhaustive analysis of the context within which each grievance is generated? Foremen and stewards might be expected to meet only the simpler demands of such continuous alertness to the factors of human relations. On the other hand, personnel managers, higherranking company executives, and union officials may well be asked to shoulder the requirements of deeper insights.

One source of difficulty is the common procedure by which the complainant is asked to submit his grievance in writing, before the matter has even been discussed with him. When the complainant is handed a form and told to state his grievance in clear short terms isn't he being invited to state his trouble in terms of some sanctioned and more or less common kind of grievance, rather than cramp into a few lines a description of some complicated, underlying emotional grievance which he himself may not fully understand or cannot express?

There is a final consideration which the administrator must keep in mind : The better he knows workers, supervisors and union officials as individual people, the more he understands informal bench groups, shop cliques, union factions into which they associate themselves, and the more clearly he realizes how changes within and without the shop community reflect themselves in the emotions and sentiments that motivate shop behavior - to that degree will he be able to handle grievances adequately, and thereby also guide shop relations to serve his administrative purposes. 